Bağcı, H. ve Baz, D. (2018). Türkçe öğretmen adaylarının yazma alışkanlıkları üzerine bir çalışma. Ana Dili Eğitimi Dergisi, 6(4), 1138-1160.

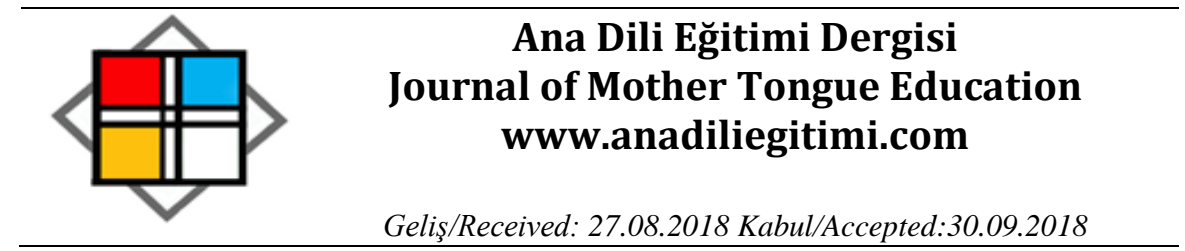

\title{
Türkçe Öğretmen Adaylarının Yazma Alışkanlıkları Üzerine Bir Çalışma
}

\author{
Hasan $B A \breve{G} C I^{*}$ \\ Dilek $B A Z^{* *}$
}

\begin{abstract}
Öz
Iletişim için önemli olan yazma becerisi bireylere, ilkokulda sınıf öğretmenleri, ortaokulda ise Türkçe Öğretmenleri tarafından kazandırılan anlatma becerisidir. Öğrencilerin Türkçe derslerinde duygu, düşünce, izlenim ve yaşadıkların doğru ve etkili bir biçimde sunabilmesi onların anlatma becerisine bağlıdır. Bu bağlamda Türkçe öğretmenlerinin, öğrencilerine neyi, nasıl yazacakları konusunda bilgilendirmeleri ve verilen bilgilerin uygulama çalışmalarıyla beceriye dönüşmesini sağlamaları gerekmektedir. Bu durumda bir Türkçe öğretmeninden beklenen yazma becerisinin gelişmiş olmasıdır. Çünkü bir Türkçe öğretmeninin yazma becerisi gelişmemişse öğrencilerinin de yazma becerisini geliştirebilmesi beklenemez. Bu sebepten dolayı öğrencilere Türkçe dersi veren bir öğretmenin yazma becerisinin gelişmiş ve yazma alışkanlığı kazanmış olması gerekmektedir. Türkçe öğretmeni adaylarııın yazma alışkanlıklarını ortaya koymayı amaçlayan bu araştırmada betimsel araştırma yöntemi kullanılarak Özdemir (2012) tarafından geliştirilen Türkçe Öğretmenliği Adayları için Yazma Alışkanlığı Ölçeği kullanılmıştır. Araştırma sonucunda "Türkçe öğretmeni adaylarının, yazma alışkanlık düzeylerinin orta seviyede olduğu belirlenmiştir.
\end{abstract}

Anahtar Kelimeler: Türkçe öğretimi, yazma becerisi, yazma alışkanlığı, yazma.

\section{A Study on the Writing Habits of Turkish Teacher Candidates}

\begin{abstract}
The writing skill that is important for communication is the speaking skill that is gained by the class teachers in the primary school and the Turkish teachers in the secondary school. The ability of the students to present feelings, thoughts, impressions, designs and experiences in Turkish classes in a correct and effective way depends on their skill of speaking. In this context, it is necessary for the Turkish teachers to inform their students about what to write and how to make the given information turned into a skill through practice studies. In this case, the writing skill expected from a Turkish teacher is developed. Because, if the writing skill of the Turkish teacher is not developed, it is unthinkable for the students to improve their writing skills. For this reason, the writing skills of a teacher who teaches Turkish to the students should have improved and become a writing habit. In this research which aims to reveal the habits of Turkish teacher candidates, descriptive research method was used for the Turkish Language Teacher Candidates developed by Özdemir (2012). At the end of the research, it was found out that "the level of writing habits of the Turkish teacher candidates is at the middle level.
\end{abstract}

Keywords: Turkish teaching, writing skills, writing habit, writing

\footnotetext{
* Doç. Dr. Hasan Bağcl, Mehmet Akif Ersoy Üniversitesi, Eğitim Fakültesi, Türkçe Eğitimi, Burdur, hbagci26@hotmail.com

** Yüksek Lisans Öğrencisi Dilek Baz, Mehmet Akif Ersoy Üniversitesi, Eğitim Fakültesi, Türkçe Eğitimi, Burdur, bazdilek4@gmail.com
} 


\section{Giriş}

Dil, duygu düşünce ve isteklerin aktarılmasını sağlayan bir araçtır. Dilin dört temel beceri alanı bulunmaktadır. Bu alanlardan anlama becerisi dinleme ile okumayken anlatma becerisi de konuşma ile yazmadır. Dil öğretiminde dört temel beceri eşit oranda önemlidir. Anlatma becerilerinden biri olan yazma, bireylerin kendilerini yazılı olarak ifade edebilmelerine fırsat sunar. Yılmaz (2008: 204), yazma becerisinin defalarca uygulama ve alıştırmalar yapılarak kazanılabileceğini, kazanılan yeteneğin çalışmalar yapılarak geliştirilebileceğini vurgularken Carter vd. (2002:246) de yazmayı bilginin elde edilmesi ve bilginin ifade edilmesi ile ilgili süreçlerden oluşan bir beceri şeklinde tanımlamaktadır. Güleryüz (akt. Özdemir, 2011: 19) de yazmanın uzun tekrarlar sonucu belli özelliklere uygun olarak öğrenilmiş şekil, grafik, sembol, rakam ve harflerin, gelen uyarıcıların algılanma, yorumlanma işlemine tabi tutularak ifade edilmesi olduğunu belirtmiştir. Benzer bir tanım da Özbay $(2006,121)$ tarafından duygu, düşünce, istek ve olayların belli kurallara uygun olarak belli sembollerle anlatılması şeklinde yapılmıştır. Tanımlardan da görüldüğü üzere yazma, belli kuralları olan ve bu kurallara bağlı kalınan şekil, sembol ve rakamların kullanılarak bireyin kendisini ifade etmesini sağlayan bir beceri alanıdır.

Yazma becerisi, okuma becerisi gibi sonradan örgün eğitim döneminde öğrenilen ve üzerinde sık tekrarlar yapılması gereken bir beceridir. Öyle ki yazma günlük hayatta sürekli karşımıza çıkan bir beceridir. Örneğin resmi bir makama bir şey arz edileceğinde dilekçe yazılmakta, bir işe girileceğinde başvuru mektubu yazılmakta, iletişim kurulabilmesi için e posta vb. yazılmaktadır. Bu derece önem arz eden yazma becerisi kalıcı olma özelliğiyle diğer becerilere nazaran üstünlükleri de bulunan bir beceridir. Yılmaz'a (2006) göre "Söz uçar, yazı kalır" sözünü benimseyerek kalıcılık adına veya gelecek nesillere kendinden bir iz bırakmak adına yazmaya çabalayan bireyler bulunmaktadır. Çağlar arasındaki iletişim çoğunlukla yazıyla sağlanmış, belki de bu nedenle yazı, bazı tarihçiler tarafından uygarlığın başlangıcı olarak kabul edilmiştir (Bülbül, 2000). Günümüzde dil becerileri arasında yazma becerisine daha az zaman ayrıldığı gözlenmektedir. Yapılan bir araştırmaya göre günlük yaşamda insanlar dinlemeye $\% 40$, konuşmaya $\% 35$, okumaya $\% 16$ ve yazmaya $\% 9$ oranında zaman ayırmaktadır (Yılmaz, 2006). Bu durum bireylerin yazma eğiliminde olmadıklarını ve yazma becerisini alışkanlığa dönüştüremediklerini göstermektedir.

Alışkanlık, bir şeye alışmış olma durumu, itiyat, huy, ünsiyet; iç ve dış etkilerle davranışların tekrarlanması, hep aynı biçimde gerçekleşmesi sonucu beliren, şartlanmış davranış (TDK, 2009: 75) olarak tanımlanmaktadır. Yazma becerisinin alışkanlığa dönüşebilmesi için bireylerin düzenli bir şekilde yazma çalışmaları yapmaları gerekmektedir. Aksi takdirde yazma alışkanlığı kazanılamaz. Bu alışkanlığı kazanamayan bireyler konuşma becerisinin yetersiz kaldığı durumlarda kendi duygu ve düşüncelerini yazılı olarak doğru bir şekilde ifade edemezler. Özbay (2010: 258), iyi ve doğru 
yazmanın kabiliyete bağlı olmadığını ifade etmiştir. İyi ve doğru yazmak için bireylerin dilin kurallarını iyi bilmesi, yazma alışkanlığına sahip olmak içinde yeterince yazma çalışması yapılması gerekir. Ancak dilin kurallarının iyi bilinmesi ve o dildeki inceliklerin anlaşılabilmesi için alanında yetkin bir Türkçe öğretmenine ihtiyaç vardır. Öyle ki Türkçe öğretmenlerinin öğrencilerin yazma becerisinin geliştirilmesine rehberlik edebilmesi, öncelikle kendilerinin yazma becerisi ile ilgili yeterli bilgi ve beceriye sahip olmasına bağlıdır (Mete, 2015).

Öğrencilere ana dili eğitimi verecek olan Türkçe öğretmenlerinde bulunması gereken en önemli özellik, hiç kuşkusuz ana dilini etkili bir şekilde sözlü ve yazılı olarak kullanabilmesidir. Bütün branşlardaki öğretmenlerin nitelikli olmasının yanı sıra Türkçe öğretmenlerinin hem kendilerini çok iyi yetiştirip eksik yanlarını gidermeleri hem de öğrencileri iyi eğitmek için yorulup usanmadan çaba göstermeleri şarttır (Kavcar, 1998: 14). Ancak öğretmenlerin kendilerini çok fazla yetiştirmedikleri, öğrencilere dört beceriyi kazandırmakta başarısız oldukları hatta üniversite sınavını kazanarak Türkçe/Türk Dili ve Edebiyatı bölümüne yerleşen öğrencilerin bile kelime serveti bakımından fakir, cümle kurma açısından yetersiz ve beceriksiz olmaları, mecazları ve ayrıntıları kavramakta zorlanmaları, ülkemizdeki ilk ve ortaöğretimin Türkçeyi konuşurken ve yazarken kullanmayı beceren insan yetiştirmeyi başaramadığını ortaya koyuyor (Tural, 1992: 43; Kaplan, 1972: 9; Güzel, 1987: 436437).

Öztürk (2007) Illköğretim Beşinci Sınıf Öğrencilerinin Yaratıcı Yazma Becerilerinin Değerlendirilmesi adlı doktora tezinde, yapılan akademik araştırmalara dayalı olarak ilköğretim okullarının yazma becerisini kazandırmada yetersiz kaldığını ifade etmiştir. Bu sonuç akla öğrencilerine yazma alışkanlığını kazandıramayan öğretmenlerin kendilerinin yazma alışkanlığının ne düzeyde olduğu sorusunu getirmektedir. Bağcı (2007) da yaptığı çalışmada Türkçe öğretmenlerinin serbest yazma, günlük tutma ve seçtikleri, beğendikleri şiirleri yazarak bir defter oluşturma gibi etkinliklerde bulunma oranlarının düşük olduğunu ifade etmiştir. Bu durum, öğretmenlerin öğrencilerine yazma alışkanlığını kazandırabilmek için öncelikle kendilerinin yazma alışkanlıklarını kazanmış olması gerektiğini göstermektedir. Bu bağlam üzerinde durulması gereken ise Türkçe öğretmeni adaylarının yazma alışkanlığının ne düzeyde olduğudur. Çamurcu (2011) yaptığı Yüksek Öğrenime Yeni Başlayan Türkçe Eğitimi Bölümü Öğrencilerinin Yazma Becerilerinin İncelenmesi adlı araştırmasında Türkçe öğretmeni adaylarının yazma becerilerini incelemiş, duygu ve düşüncelerini yazılı olarak ifade edebilme düzeylerinin düşük olduğunu tespit etmiştir.

Özdemir ve Erdem (2011) tarafından yapılan Türkçe Öğretmeni Adaylarının Yazma Alışkanlıklarının Bazı Değişkenler Açısından İncelenmesi adlı çalışmada da Türkçe öğretmeni adaylarının yazma alışkanlıklarının düşük olduğu belirlenmiştir bütün bu yapılan çalışmalar doğrultusunda Türkçe öğretmenlerinin öğrencilerine yazma alışkanlığını kazandırma durumunun 
oldukça zayıf olduğu söylenebilir. Hatta bu durum artık öyle bir hâl almıştır ki bu bölümü okuyan öğretmen adaylarının bile yeterli düzeyde olmadığı gözlenmektedir. Bu bakımdan çalışmada Türkçe öğretmeni adaylarının yazma alışkanlıkları ile öğretmen adaylarının yazma alışkanlıklarına etki eden unsurlar belirlenmeye çalışılacaktır. Çünkü geleceğin öğretmeni olacak bugünün öğretmen adaylarının bile yazma alışkanlığı gelişmemiş ise öğrencilerine bu alışkanlığı kazandırabilmeleri mümkün değildir. Bu çalışma mevcut sorunların çözümüne yardımcı olacağından önem arz etmektedir.

Bu çalışmanın amacı, Türkçe öğretmeni adaylarının yazma alışkanlıklarının bazı değişkenler açısından incelenmesidir. Bu temel amaç doğrultusunda aşağıdaki sorulara cevap aranacaktır:

1. Türkçe öğretmeni adayları, yazma alışkanlığına ne düzeyde sahiptir?

2. Türkçe öğretmeni adaylarının yazma alışkanlıkları cinsiyet değişkenine göre anlamlı düzeyde farklıık göstermekte midir?

3. Türkçe öğretmeni adaylarının yazma alışkanlıkları serbest yazma etkinlikleri yapma değişkenine göre anlamlı düzeyde farklııık göstermekte midir?

4.Türkçe öğretmeni adaylarının yazma alışkanlıkları serbest yazma etkinliklerini sevme durumu değişkenine göre anlamlı düzeyde farklılık göstermekte midir?

5. Türkçe öğretmeni adaylarının yazma alışkanlıkları yazma etkinlikleri yaparken kaygı duyma durumu değişkenine göre anlamlı düzeyde farklılık göstermekte midir?

6. Türkçe öğretmeni adaylarının yazma alışkanlıkları bu alışkanlığı kazanma değişkenine göre anlamlı düzeyde farklılık göstermekte midir?

7. Türkçe öğretmeni adaylarının yazma alışkanlıkları akademik başarı durumu değişkenine göre anlamlı düzeyde farklılık göstermekte midir?

8. Türkçe öğretmeni adaylarının yazma alışkanlıkları yazııı anlatım dersi akademik başarı değişkenine göre anlamlı düzeyde farklılık göstermekte midir?

9. Türkçe öğretmeni adaylarının yazma alışkanlıkları sınıf değişkenine göre anlamlı düzeyde farklılık göstermekte midir?

\section{Yöntem}

\section{Araştırmanın Modeli}

Türkçe öğretmeni adaylarının yazma alışkanlıklarını ortaya koymayı amaçlayan bu araştırmada betimsel araştırma yöntemi kullanıımıştır. Betimsel araştırmalar "verilen bir durumu olabildiğince tam ve dikkatli bir şekilde tanımlar" (Büyüköztürk vd., 2011: 21). Yine bu araştırmada betimsel araştırmanın yanında ilişkisel araştırma modelinin nedensel karşılaştırma yönteminden de faydalanılmıştır. İlişkisel araştırma, iki ya da daha fazla sayıdaki değişkenin arasında birlikte değişim 
varlığını ve/veya derecesini belirlemeyi amaçlar (Karasar, 2006: 81). Bu yöntemde, bağımsız değişkenin olaya etki ettiği durumla etki etmediği durum karşılaştırılır (İslamoğlu,2009: 85).

\section{Örneklem / Araştırma grubu}

Araştırmanın evrenini, 2017-2018 eğitim-öğretim yılı bahar yarıyılında öğrenim gören Türkçe eğitimi bölümü öğrencileri oluşturmaktadır. Araştırmada uygun örnekleme yöntemi kullanılmıştır. Bu yönteme göre araştırmacı ihtiyaç duyduğu büyüklükteki bir gruba ulaşana kadar en ulaşılabilir olan yanıtlayıcılardan başlayarak örneklem oluşturulur (Büyüköztürk vd. 2011: 91). Bu amaçla Mehmet Akif Ersoy Üniversitesi Eğitim Fakültesi Türkçe Eğitimi Ana Bilim Dalı’nda öğrenim gören 1. 2. 3. ve 4. sınıflardan oluşan 250 öğretmen adayına ulaşılmıştır. Ancak geri dönen ölçek formları arasından 224 öğrenci araştırmaya dâhil edilmiştir.

\section{Veri Toplama Araçları}

Bu araştırmada veriler, 5'li likert tipi 25 maddelik Yazma Alışkanlığı Ölçeğinden yararlanılarak elde edilmiştir. Özdemir (2011) tarafından geliştirilen ölçek $V$ faktörden oluşmaktadır. Ölçeğin güvenilirliği için Cronbach Alfa iç tutarlılık katsayısı, test-tekrar test kararlılık katsayısı, düzeltilmiş madde toplam korelasyonları ve \%27'lik alt ve üst grup ortalamalarının karşılaştırılmasına ilişkin t değerleri hesaplanarak test edilmiştir. Cronbach Alfa iç tutarlılık katsayılarının I. faktör için .904, II. faktör için .773, III. faktör için .728, IV. faktör için .768 ve V. faktör içinse .559 olarak hesaplandığı görülmüştür. Özdemir (2011: 110), genel olarak güvenirlik katsayısının .90 civarında mükemmel, .80 civarında çok iyi, .70 civarında yeterli, .50'nin altında ise yetersiz olduğunu belirtmektedir. Buna göre ölçek için hesaplanan Cronbach Alfa iç tutarlılık katsayısının, V. faktör hariç tüm faktörler için mükemmel ya da çok iyi değerler verdiği, V. faktör için ise .70'ten yüksek olmamakla birlikte yetersiz olmadığı görülmüştür. Ölçeğin kararlııı açısından güvenirliğini gösteren test-tekrar test güvenilirlik katsayıları I. faktör için .768, II. faktör için .823, III. faktör için .745, IV. faktör için .710 ve V. faktör içinse .630 olarak hesaplanmıştır. Test-tekrar test güvenirliliği için hesaplanan korelasyon katsayıların strateji boyutu için orta diğerleri için yüksek düzeyde bulunması, ölçeğin zamana bağlı olarak kararlı ölçümler verdiği şeklinde yorumlanabilir (Özdemir, 2011: 110). Ölçeğin her bir faktöründe yer alan maddeler için hesaplanan düzeltilmiş madde-toplam korelasyonların .843 ile .337 arasında değiştiği ve tüm maddeler için alt ve üst \%27'lik gruplar arasında karşılaştırmaların anlamlı düzeyde farklılaştığı görülmektedir. Bu sonuç, maddelerin yer aldıkları faktörlerle aynı davranışı ölçmeye yönelik maddeler olduğunu ve yazma alışkanlıkları açısından öğrencileri ayırt edicilik düzeylerinin yüksek olduğu şeklinde yorumlanabilir (Özdemir, 2011: 111). 
Türkçe Öğretmeni Adaylarının Yazma Alışkanlıkları Üzerine Bir Çalışma

\section{Verilerin Toplanması ve Analizi}

Araştırmada uygulanan ölçekte yazma alışkanlığına ait 5 alt boyutta toplam 25 madde yer almaktadır. Araştırmadan elde edilen veriler spss 21.00 programı yardımıyla istatistiki olarak değerlendirilecektir.

Ölçekteki puanlama aşağıdaki gibidir:

1.00- 1.80 Hiçbir zaman

1.81- 2.60 Nadiren

2.61- 3.40 Ara sıra

3.41- 4.20 Sık sık

4.21- 5.00 Her zaman.

\section{Bulgular}

\section{Birinci Alt Probleme Ait Bulgular}

Araştırmada, "Türkçe öğretmeni adayları, yazma alışkanlığına ne düzeyde sahiptir?" olarak ifade edilen birinci alt problemle ilgili elde edilen bulgular ve yorumları aşağıda verilmiştir.

Tablo 1. Türkçe öğretmeni adaylarının yazma alışkanlıklarının düzeylere göre sonuçları

\begin{tabular}{|c|c|c|c|c|c|c|}
\hline Boyut & $\mathbf{N}$ & $x$ & Min. & Max. & SS & Düzey \\
\hline Toplam & 224 & 3,21 & 1,88 & 6,08 & 0,54 & Orta \\
\hline
\end{tabular}

Araştırmadan elde edilen bulgulara göre Türkçe öğretmen adaylarının, yazma alışkanlık düzeylerinin $(\mathbf{X}=3,21)$ ile orta seviyede olduğu belirlenmiştir.

\section{Ikinci Alt Probleme Ait Bulgular}

Araştırmada, "Türkçe öğretmeni adaylarının yazma alışkanlıkları cinsiyet değişkenine göre anlamlı düzeyde farklılık göstermekte midir?" olarak ifade edilen ikinci alt problemle ilgili elde edilen bulgular ve yorumları aşağıda verilmiştir.

Tablo 2. Türkçe öğretmeni adaylarının yazma alışkanlıklarının cinsiyet değişkenine göre t-testi sonuçları

\begin{tabular}{|c|c|c|c|c|c|c|c|}
\hline Boyut & Cinsiyet & $\mathrm{N}$ & $x$ & SS & df & $\mathrm{t}$ & $p$ \\
\hline Yazım kuralları ve & & & & & & 1,847 & 066 \\
\hline \multirow{2}{*}{$\begin{array}{l}\text { noktalama işaretlerine } \\
\text { uyma }\end{array}$} & $\mathrm{K} ı \mathrm{z}$ & 149 & 4,2550 & ,68433 & 222 & & \\
\hline & Erkek & 75 & 4,0578 & ,87786 & & & \\
\hline
\end{tabular}




\begin{tabular}{|c|c|c|c|c|c|c|c|}
\hline Yazma yeterliliği & Kız & 149 & 3,7478 & 93713 & \multirow[t]{2}{*}{222} &, 553 & \multirow[t]{2}{*}{,0581 } \\
\hline & Erkek & 75 & 3,6800 & 70215 & & \multirow[b]{2}{*}{2,539} & \\
\hline Yazıyı edebi tür olarak & Kız & 149 & 2,3463 & ,73948 & 222 & & ,012 \\
\hline & Erkek & 75 & 2,0880 & ,67483 & \multirow[b]{2}{*}{222} & \multirow[b]{2}{*}{$-2,104$} & \multirow[b]{2}{*}{,036 } \\
\hline Yazıyı iletişim aracı olarak & Kız & 149 & 2,2836 & ,92253 & & & \\
\hline & Erkek & 75 & 2,5567 & ,90473 & & \multirow[b]{2}{*}{,800 } & \multirow[b]{2}{*}{,424 } \\
\hline $\begin{array}{l}\text { Yazma stratejileri } \\
\text { kullanma }\end{array}$ & KIz & 149 & 2,7875 & ,85619 & 222 & & \\
\hline \multirow{3}{*}{ Ortalama/ Toplam } & Erkek & 75 & 2,6889 & 89767 & \multirow{3}{*}{222} & \multirow{3}{*}{1,125} & \multirow{3}{*}{,262 } \\
\hline & Kız & 149 & 3,2397 & ,53872 & & & \\
\hline & Erkek & 75 & 3,1536 & ,54458 & & & \\
\hline
\end{tabular}

Tablo 2'de Türkçe öğretmeni adaylarının yazma alışkanlıklarının cinsiyet değişkenine göre karşılaştırılması amacıyla bağımsız t-testi yapılmıştır. Yapılan t-testi sonucuna göre, öğretmen adaylarının yazma alışkanlıklarının cinsiyet değişkeni açısından ölçeğin bütün boyutlarını oluşturan toplamında anlamlı farklılık oluşturmadığı görülmüştür [ $\left.t_{(222)}=1,125, p>.05\right]$.

Yapılan analiz sonucuna göre, kız ve erkek öğretmen adayları karşılaştırıldığında kız öğretmen adaylarının $(X=3,2397)$ erkek öğretmen adaylarından $(X=3,1536)$, yazma alışkanlıkları puanlarının daha yüksek olduğu görülmüştür. Bu sonuçlardan kız öğretmen adaylarının yazma alışkanlıklarının erkek öğretmen adaylarına göre daha yüksek olduğu söylenebilir.

Türkçe öğretmen adaylarının yazma alışkanlıklarının cinsiyet değişkeni açısından ölçeğin "yazıyı edebi tür olarak kullanma" boyutunda kız öğretmen adayları lehine anlamlı farklılık oluşurken $\left[t_{(222)=} 2,539, p<.05\right]$, ölçeğin "yazıyı iletişim aracı olarak kullanma" boyutunda ise erkek öğretmen adaylarının lehine anlamlı farklılık oluşmuştur. [t(222)= $-2,104, p<.05]$.

\section{Üçüncü Alt Probleme Ait Bulgular}

Araştırmada, "Türkçe öğretmeni adaylarının yazma alışkanlıkları serbest yazma etkinlikleri yapma değişkenine göre anlamlı düzeyde farklılık göstermekte midir?" olarak ifade edilen üçüncü alt problemle ilgili elde edilen bulgular ve yorumlar aşağıda verilmiştir.

Tablo 3. Türkçe öğretmeni adaylarının yazma alışkanlıklarının serbest yazma etkinlikleri yapma değişkenine göre t-testi sonuçları

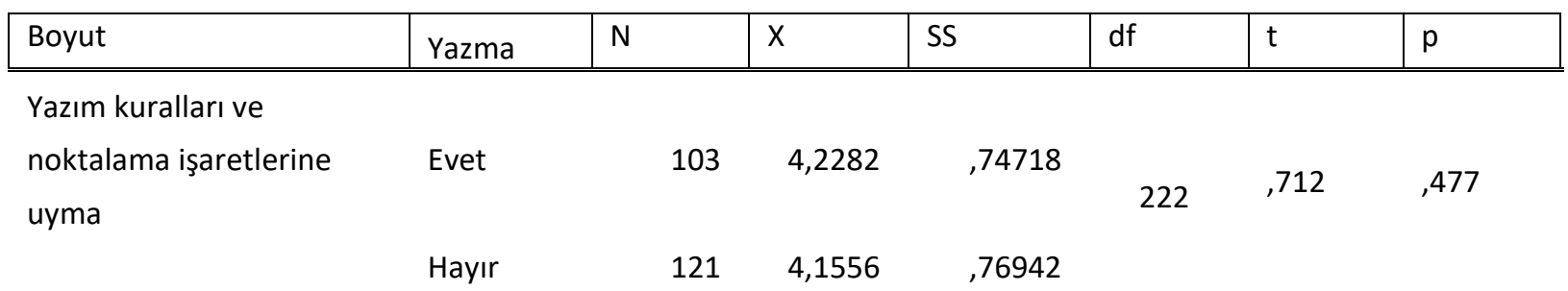


Türkçe Öğretmeni Adaylarının Yazma Alışkanlıkları Üzerine Bir Çalışma

\begin{tabular}{|c|c|c|c|c|c|c|c|}
\hline Yazma yeterliliği & Evet & 103 & 3,9417 & 1,04853 & 222 & 3,549 & ,000 \\
\hline & Hayır & 121 & 3,5407 & 61644 & \multirow[b]{2}{*}{222} & \multirow[b]{2}{*}{8,471} & \multirow[b]{2}{*}{, 000 } \\
\hline Yazıyı edebi tür olarak & Evet & 103 & 2,6485 & ,67532 & & & \\
\hline & Hayır & 121 & 1,9289 & -59602 & & \multirow[b]{2}{*}{2,819} & \multirow[b]{2}{*}{,005 } \\
\hline Yazıyı iletişim aracı olarak & Evet & 103 & 2,5607 & 93572 & 222 & & \\
\hline \multirow[b]{2}{*}{$\begin{array}{l}\text { Yazma stratejileri } \\
\text { kullanma }\end{array}$} & Hayır & 121 & 2,2169 & 88679 & & \multirow[b]{2}{*}{3,579} & \multirow[b]{2}{*}{, 000 } \\
\hline & Evet & 103 & 2,9741 & 83456 - r n & 222 & & \\
\hline \multirow{3}{*}{ Ortalama/ Toplam } & Hayır & 121 & 2,5675 & 85813 & \multirow{3}{*}{222} & \multirow{3}{*}{5,539} & \multirow{3}{*}{,000 } \\
\hline & Evet & 103 & 3,4148 & -54957 & & & \\
\hline & Hayır & 121 & 3,0374 & ,47025 & & & \\
\hline
\end{tabular}

Tablo 3'te Türkçe öğretmeni adaylarının yazma alışkanlıklarının serbest yazma etkinlikleri yapma değişkenine göre karşılaştırılması amacıyla bağımsız t-testi yapıımıştır. Yapılan t-testi sonucuna göre, Öğretmen adaylarının yazma alışkanlıklarının serbest yazma etkinlikleri yapma değişkeni açısından ölçeğin bütün boyutlarını oluşturan toplamında anlamlı farklılık oluşturduğu görülmüştür [t(222)= 5,539, $p<.05]$.

Yapılan analiz sonucuna göre, serbest yazma etkinlikleri yapan öğretmen adaylarının $(X=3,4148)$ serbest yazma etkinlikleri yapmayan öğretmen adaylarından $(X=3,0374)$, yazma alışkanlıkları puanlarının daha yüksek olduğu görülmüştür. Bu sonuçlardan serbest yazma etkinlikleri yapan öğretmen adaylarının yazma alışkanlıklarının serbest yazma etkinlikleri yapmayan öğretmen adaylarına göre daha yüksek düzeyde olduğu söylenebilir.

Türkçe öğretmeni adaylarının yazma alışkanlıklarının serbest yazma etkinlikleri yapma değişkeni açısından ölçeğin "yazma yeterliliği, yazıyı edebi tür olarak kullanma, yazıyı iletişim aracı olarak kullanma, yazma stratejileri kullanma boyutlarında" serbest yazma etkinlikleri yapan öğretmen

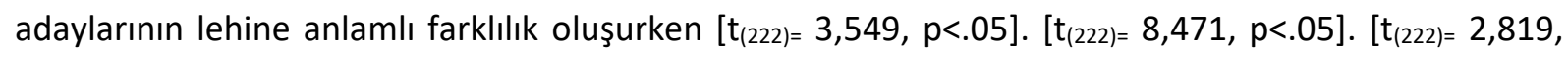

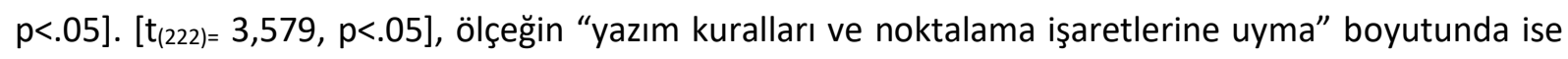
anlamlı farklılık oluşmamıştır [t(222)= $, 712, p>05]$.

Dördüncü Alt Probleme Ait Bulgular

Araştırmada, "Türkçe öğretmeni adaylarının yazma alışkanlıkları serbest yazma etkinliklerini sevme durumu değişkenine göre anlamlı düzeyde farklılık göstermekte midir?" olarak ifade edilen dördüncü alt problemle ilgili elde edilen bulgular ve yorumlar aşağıda verilmiştir. 
Tablo 4. Türkçe öğretmeni adaylarının yazma alışkanlıklarının serbest yazma etkinliklerini sevme durumu değişkenine göre t-testi sonuçları

\begin{tabular}{|c|c|c|c|c|c|c|c|}
\hline Boyut & sevme & $\mathrm{N}$ & $x$ & SS & df & T & $p$ \\
\hline \multicolumn{8}{|l|}{ Yazım kuralları ve } \\
\hline \multirow{2}{*}{$\begin{array}{l}\text { noktalama işaretlerine } \\
\text { uyma }\end{array}$} & Evet & 137 & 4,2518 & ,73212 & \multirow{2}{*}{222} & \multirow[t]{2}{*}{1,561} & 120 \\
\hline & Hayır & 87 & 4,0900 & 79233 & & & \\
\hline \multirow[t]{2}{*}{ Yazma yeterliliği } & Evet & 137 & 3,8895 & ,95628 & \multirow[t]{2}{*}{222} & \multirow[t]{2}{*}{3,668} & \multirow[t]{2}{*}{,000 } \\
\hline & Hayır & 87 & 3,4663 & 61752, & & & \\
\hline \multirow{2}{*}{$\begin{array}{l}\text { Yazıyı edebi tür olarak } \\
\text { kullanma }\end{array}$} & Evet & 137 & 2,5212 & 70892, & \multirow[t]{2}{*}{222} & 7,549 & ,000 \\
\hline & Hayır & 87 & 1,8483 & ,54471 & & \multirow[b]{2}{*}{2,309} & \multirow[b]{2}{*}{022} \\
\hline \multirow[t]{2}{*}{$\begin{array}{l}\text { Yazıyı iletişim aracı olarak } \\
\text { kullanma }\end{array}$} & Evet & 137 & 2,4872 & 93213 & \multirow[t]{2}{*}{222} & & \\
\hline & Hayır & 87 & 2,1983 & 88687 & & \multirow[b]{2}{*}{3,725} & \multirow[b]{2}{*}{, 000 } \\
\hline \multirow[t]{2}{*}{$\begin{array}{l}\text { Yazma stratejileri } \\
\text { kullanma }\end{array}$} & Evet & 137 & 2,9221 & ,82769 & \multirow[t]{2}{*}{222} & & \\
\hline & Hayır & 87 & 2,4904 & ,87284 & & \multirow{3}{*}{5,604} & \multirow{3}{*}{,000 } \\
\hline \multirow[t]{2}{*}{ Ortalama/ Toplam } & Evet & 137 & 3,3623 & ,52137 & \multirow[t]{2}{*}{222} & & \\
\hline & Hayır & 87 & 2,9724 & 48476 & & & \\
\hline
\end{tabular}

Tablo 4'te Türkçe öğretmeni adaylarının yazma alışkanlıklarının serbest yazma etkinlikleri yapmayı sevme değişkenine göre karşılaştırılması amacıyla bağımsız t-testi yapılmıştır. Yapılan t-testi sonucuna göre, öğretmen adaylarının yazma alışkanlıklarının serbest yazma etkinlikleri yapmayı sevme değişkeni açısından ölçeğin bütün boyutlarını oluşturan toplamında anlamlı bir fark oluşturduğu görülmüştür $\left[\mathrm{t}_{(222)=} 5,604, p<.05\right]$.

Yapılan analiz sonucuna göre, serbest yazma etkinlikleri yapmayı seven öğretmen adaylarının $(X=3,3623)$ serbest yazma etkinlikleri yapmayı sevmeyen öğretmen adaylarından $(X=2,9724)$, yazma alışkanlıkları puanlarının daha yüksek olduğu görülmüştür. Bu sonuçlardan serbest yazma etkinlikleri yapmayı seven öğretmen adaylarının yazma alışkanlıklarının serbest yazma etkinlikleri yapmayı sevmeyen öğretmen adaylarına göre daha yüksek seviyede olduğu söylenebilir.

Türkçe öğretmeni adaylarının yazma alışkanlıklarının serbest yazmayı sevme değişkeni açısından ölçeğin "yazma yeterliliği, yazıyı edebi tür olarak kullanma, yazıyı iletişim aracı olarak kullanma, yazma stratejileri kullanma" boyutlarında serbest yazma etkinlikleri yapmayı seven öğretmen adayları lehine anlamlı farklar oluşurken $\left[t_{(222)}=3,668, p<.05\right],\left[t_{(222)=7,549,} p<.05\right],\left[t_{(222)=}\right.$ $2,309, p<.05],\left[t_{(222)=} 3,725, p<.05\right]$, "yazım kuralları ve noktalama işaretlerine uyma" boyutunda ise

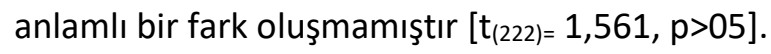


Türkçe Öğretmeni Adaylarının Yazma Alışkanlıkları Üzerine Bir Çalışma

\section{Beşinci Alt Probleme Ait Bulgular}

Araştırmada, "Türkçe öğretmeni adaylarının yazma alışkanlıklarının yazma etkinlikleri yaparken kaygı duyma durumu değişkenine göre anlamlı düzeyde farklıık göstermekte midir?" olarak ifade edilen beşinci alt problemle ilgili elde edilen bulgular ve yorumları aşağıda verilmiştir.

Tablo 5. Türkçe öğretmeni adaylarının yazma alışkanlıklarının yazma etkinlikleri yaparken kaygı duyma durumu değişkenine göre t-testi sonuçları

\begin{tabular}{|c|c|c|c|c|c|c|c|}
\hline Boyut & kaygı & $\mathrm{N}$ & $x$ & SS & $d f$ & $\mathrm{t}$ & $p$ \\
\hline \multicolumn{8}{|l|}{ Yazım kuralları ve } \\
\hline noktalama işaretlerine & Evet & 139 & 4,0803 & ,76254 & \multirow[t]{2}{*}{222} & \multirow[t]{2}{*}{2,783} & \multirow[t]{2}{*}{,006 } \\
\hline \multirow{3}{*}{ Yazma yeterliliği } & Hayır & 85 & 4,3667 & 72137 & & & \\
\hline & Evet & 139 & 3,6043 & 63360 & \multirow[t]{2}{*}{222} & \multirow[t]{2}{*}{2,712} & \multirow[t]{2}{*}{,007 } \\
\hline & Hayır & 85 & 3,9227 & 1,12303 & & & \\
\hline \multirow[t]{2}{*}{$\begin{array}{l}\text { Yazıyı edebi tür olarak } \\
\text { kullanma }\end{array}$} & Evet & 139 & 2,2115 & ,72503 & 222 & 1,273 & 204 \\
\hline & Hayır & 85 & 2,3388 & 72835 & \multirow[b]{2}{*}{222} & \multirow[b]{2}{*}{2,314} & \multirow[b]{2}{*}{022} \\
\hline \multirow[t]{2}{*}{$\begin{array}{l}\text { Yazıyı iletişim aracı olarak } \\
\text { kullanma }\end{array}$} & Evet & 139 & 2,2644 & 90728 & & & \\
\hline & Hayır & 85 & 2,5559 & ,92693 & & \multirow[b]{2}{*}{,- 718} & \multirow[b]{2}{*}{ 474 } \\
\hline \multirow[t]{2}{*}{$\begin{array}{l}\text { Yazma stratejileri } \\
\text { kullanma }\end{array}$} & Evet & 139 & 2,7218 & 89514 & 222 & & \\
\hline & Hayır & 85 & 2,8078 & ,82836 & \multirow{3}{*}{222} & \multirow{3}{*}{$-3,296$} & \multirow{3}{*}{,001 } \\
\hline \multirow[t]{2}{*}{ Ortalama/ Toplam } & Evet & 139 & 3,1197 & 50771 & & & \\
\hline & Hayır & 85 & 3,3600 & ,56326 & & & \\
\hline
\end{tabular}

Tablo 5'te Türkçe öğretmeni adaylarının yazma alışkanlıklarının yazma etkinlikleri yaparken kaygı duyma durumu değişkenine göre karşılaştırılması amacıyla bağımsız t-testi yapıımıştır. Yapılan t-testi sonucuna göre, öğretmen adaylarının yazma alışkanlıklarının yazma etkinlikleri yaparken kaygı duyma durumu değişkeni açısından ölçeğin bütün boyutlarını oluşturan toplamında anlamlı farklılık oluşturduğu görülmüştür [t(222)=-3,296, $\mathrm{p}<05]$.

Yapılan analiz sonucuna göre, yazma etkinlikleri yaparken kaygı duymayan öğretmen adaylarının $(X=3,3600)$, yazma etkinlikleri yaparken kaygı duyan öğretmen adaylarından $(X=3,1197)$, yazma alışkanlıkları puanlarının daha yüksek olduğu görülmüştür. Bu sonuçlardan yazma etkinlikleri yaparken kaygı duymayan öğretmen adaylarının yazma alışkanlıklarının yazma etkinlikleri yaparken kaygı duyan öğretmen adaylarına göre daha yüksek olduğu söylenebilir.

Türkçe öğretmen adaylarının yazma etkinliği yaparken kaygı duyma durumu değişkeni açısından ölçeğin "yazım kuralları ve noktalama işaretlerine uyma, yazma yeterliliği, yazıyı iletişim aracı olarak kullanma" boyutlarında yazma etkinliği yaparken kaygı duymayan öğretmen adayları 
lehine anlamlı fark oluşurken [ $\left.\mathrm{t}_{(222)}=2,783, p<.05\right]$, [ $\left.\mathrm{t}_{(222)}=2,712, p<.05\right],\left[\mathrm{t}_{(222)}=2,314, p<.05\right]$, ölçeğin "yazıyı edebi tür olarak kullanma ve yazma stratejileri kullanma" boyutlarında ise anlamlı bir fark oluşmamıştır [t(222)=1,273, p>.05], [t(222)= -,718, p>.05].

\section{Altıncl Alt Probleme Ait Bulgular}

Araştırmada, "Türkçe öğretmeni adaylarının yazma alışkanlıklarının yazma alışkanlığını kazandığını düşünme durumu değişkenine göre anlamlı düzeyde farklılık göstermekte midir?" olarak ifade edilen altıncı alt problemle ilgili elde edilen bulgular ve yorumlar aşağıda verilmiştir.

Tablo 6. Türkçe öğretmeni adaylarının yazma alışkanlıklarının yazma alışkanlığını kazandığını düşünme durumu değişkenine göre t-testi sonuçları

\begin{tabular}{|c|c|c|c|c|c|c|c|}
\hline Boyut & kazanım & $\mathrm{N}$ & $x$ & SS & $\mathrm{df}$ & $\mathrm{t}$ & $\mathrm{p}$ \\
\hline \multirow[t]{2}{*}{$\begin{array}{l}\text { Yazım kuralları ve } \\
\text { noktalama işaretlerine } \\
\text { uyma }\end{array}$} & Evet & 91 & 4,2527 & 73045 & \multirow[t]{2}{*}{222} & \multirow[t]{2}{*}{1,041} & ,299 \\
\hline & Hayır & 133 & 4,1454 & 77672 & & & \\
\hline \multirow[t]{2}{*}{ Yazma yeterliliği } & Evet & 91 & 3,9984 & 1,07739 & \multirow[t]{2}{*}{222} & \multirow[t]{2}{*}{4,046} & \multirow[t]{2}{*}{, 000} \\
\hline & Hayır & 133 & 3,5381 & 62018 & & & \\
\hline \multirow[t]{2}{*}{$\begin{array}{l}\text { Yazıyı edebi tür olarak } \\
\text { kullanma }\end{array}$} & Evet & 91 & 2,5824 & 72642 & 222 & 5,892 & , 000 \\
\hline & Hayır & 133 & 2,0391 & ,64265 & & \multirow[b]{2}{*}{1,570} & \multirow[b]{2}{*}{ 118 } \\
\hline $\begin{array}{l}\text { Yazıyı iletişim aracı olarak } \\
\text { kullanma }\end{array}$ & Evet & 91 & 2,4918 & 91093 & 222 & & \\
\hline \multirow[t]{2}{*}{$\begin{array}{l}\text { Yazma stratejileri } \\
\text { kullanma }\end{array}$} & $\begin{array}{l}\text { Hayır } \\
\text { Evet }\end{array}$ & $\begin{array}{r}133 \\
91\end{array}$ & $\begin{array}{l}2,2951 \\
2,9744\end{array}$ & $\begin{array}{l}92720 \\
, 85812\end{array}$ & 222 & 3,195 & ,002 \\
\hline & Hayır & 133 & 2,6040 & 84800 & \multirow{3}{*}{222} & \multirow{3}{*}{4,835} & \multirow{3}{*}{,000 } \\
\hline \multirow[t]{2}{*}{ Ortalama/Toplam } & Evet & 91 & 3,4123 & ,56787 & & & \\
\hline & Hayır & 133 & 3,0731 & ,47695 & & & \\
\hline
\end{tabular}

Tablo 6'da Türkçe öğretmeni adaylarının yazma alışkanlıklarının yazma alışkanlığını kazandığını düşünme durumu değişkenine göre karşılaştırılması amacıyla bağımsız t-testi yapılmıştır. Yapılan t-testi sonucuna göre, öğretmen adaylarının yazma alışkanlıklarının yazma alışkanlığını kazandığını düşünme durumu değişkeni açısından ölçeğin bütün boyutlarını oluşturan toplamında anlamlı farklılık oluşturduğu görülmüştür [t(222)=-4,835, p<.05].

Yapılan analiz sonucuna göre, yazma alışkanlığı kazandığını düşünen öğretmen adaylarının $(X=3,4123)$, yazma alışkanlığını kazanmadığını düşünen öğretmen adaylarından $(X=3,0731)$, yazma alışkanlıkları puanlarının daha yüksek olduğu görülmüştür. Bu sonuçlardan yazma alışkanlığı kazandığını düşünen öğretmen adaylarının yazma alışkanlığının, yazma alışkanlığı kazanmadığını düşünen öğretmen adaylarına göre daha yüksek seviyede olduğu söylenebilir. 
Türkçe Öğretmeni Adaylarının Yazma Alışkanlıkları Üzerine Bir Çalışma

Türkçe öğretmeni adaylarının yazma alışkanlığı kazandıklarını düşünme durumu değişkeni açısından ölçeğin, "yazma yeterliliği, yazıyı edebi tür olarak kullanma, yazma stratejileri kullanma" boyutlarında yazma alışkanlığı kazandığını düşünen öğretmen adayları lehine anlamlı fark oluşurken [t(222)= 4,046, $\mathrm{p}<.05],[\mathrm{t}(222)=5,892, \mathrm{p}<.05],[\mathrm{t}(222)=3,195, \mathrm{p}<.05]$, ölçeğin "yazım kuralları ve noktalama işaretlerine uyma ve yazıyı iletişim aracı olarak kullanma" boyutlarında ise anlamlı bir fark oluşmamıştır [t(222)=1,041, p>.05], [t(222)=3,195,p>.05].

\section{Yedinci Alt Probleme Ait Bulgular}

Araştırmada, "Türkçe öğretmeni adaylarının yazma alışkanlık durumlarının akademik başarı değişkenine göre anlamlı düzeyde farklılık göstermekte midir?” olarak ifade edilen yedinci alt problemle ilgili elde edilen bulgular ve yorumlar aşağıda verilmiştir.

Tablo 7.1. Türkçe Öğretmeni Adaylarının Yazma Alışkanlık Durumlarııı Akademik Başarı Değişkenine Göre ANOVA Sonuçları

ANOVA

\begin{tabular}{|c|c|c|c|c|c|c|c|}
\hline Boyut & & KT & df & KO & $\bar{F}$ & 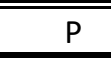 & Fark(tukey) \\
\hline \multirow{3}{*}{$\begin{array}{l}\text { Yazım kuralları ve } \\
\text { noktalama işaret. } \\
\text { uyma }\end{array}$} & Gruplararası & 3,409 & 4 &, 852 & 1,495 & ,205 & \\
\hline & Gruplariçi & 124,868 & 219 & ,570 & & & \\
\hline & Toplam & 128,277 & 223 & & & & \\
\hline \multirow{3}{*}{ Yazma yeterliliği } & Gruplararası & 4,721 & 4 & 1,180 & 1,596 & 176 & \\
\hline & Gruplariçi & 161,967 & 219 & 740 & & & \\
\hline & Toplam & 166,688 & 223 & & & & \\
\hline \multirow{3}{*}{$\begin{array}{l}\text { Yazıyı Edebi tür } \\
\text { olarak kullanma }\end{array}$} & Gruplararası & 4,389 & 4 & 1,097 & 2,116 & ,080 & \\
\hline & Gruplariçi & 113,570 & 219 & ,519 & & & \\
\hline & Toplam & 117,958 & 223 & & & & \\
\hline \multirow{3}{*}{$\begin{array}{l}\text { Yazıyı iletişim aracı } \\
\text { olarak kullanma }\end{array}$} & Gruplararası & 3,419 & 4 & 855 & 1,002 & 407 & \\
\hline & Gruplariçi & 186,831 & 219 & 853 & & & \\
\hline & Toplam & 190,250 & 223 & & & & \\
\hline \multirow{3}{*}{$\begin{array}{l}\text { Yazma stratejileri } \\
\text { kullanma }\end{array}$} & Gruplararası & 9,596 & 4 & 2,399 & 3,304 & 012 & $1<4$ \\
\hline & Gruplariçi & 159,010 & 219 & ,726 & & & \\
\hline & Toplam & 168,607 & 223 & & & & \\
\hline \multirow{3}{*}{ Toplam } & Gruplararası & 4,094 & 4 & 1,024 & 3,664 & ,007 & $1<2,3,4,5$ \\
\hline & Gruplariçi & 61,173 & 219 & 279 & & & \\
\hline & Toplam & 65,268 & 223 & & & & \\
\hline
\end{tabular}


Tablo 7.2. Türkçe Öğretmeni Adaylarının Yazma Alışkanlık Durumlarının Akademik Başarı Değişkenine Göre ANOVA Sonuçlarının Betimsel Değerleri

\begin{tabular}{|c|c|c|c|c|}
\hline & & $\mathrm{N}$ & $x$ & SS \\
\hline \multirow{6}{*}{$\begin{array}{l}\text { Yazım kuralları ve noktalama } \\
\text { işaret. Uy. }\end{array}$} & $51-60$ & 6 & 3,4722 & 1,27112 \\
\hline & $61-70$ & 37 & 4,1712 & ,77329 \\
\hline & $71-80$ & 82 & 4,1931 & 77001, \\
\hline & $81-90$ & 82 & 4,2500 & 70334 \\
\hline & $91-100$ & 17 & 4,1667 & 66927 \\
\hline & Total & 224 & 4,1890 & ,75844 \\
\hline \multirow{5}{*}{ Yazma yeterliliği } & $51-60$ & 6 & 3,0238 & ,63514 \\
\hline & $61-70$ & 37 & 3,6680 & 69746 \\
\hline & $71-80$ & 82 & 3,6655 & 65838 \\
\hline & $81-90$ & 82 & 3,8519 & 1,11551 \\
\hline & $91-100$ & 17 & 3,7731 & 63899 \\
\hline \multirow{7}{*}{ Yazıyı Edebi tür olarak kullanma } & Total & 224 & 3,7251 & ,86457 \\
\hline & $51-60$ & 6 & 1,4333 & 38816 \\
\hline & $61-70$ & 37 & 2,2973 & ,83616 \\
\hline & $71-80$ & 82 & 2,2463 & 68371 \\
\hline & $81-90$ & 82 & 2,3049 & ,70429 \\
\hline & $91-100$ & 17 & 2,3176 & ,77479 \\
\hline & Total & 224 & 2,2598 & 72730 \\
\hline \multirow{6}{*}{$\begin{array}{l}\text { Yazıyı iletişim aracı olarak } \\
\text { kullanma }\end{array}$} & $51-60$ & 6 & 1,7500 & 1,00000 \\
\hline & $61-70$ & 37 & 2,3176 & ,91220 \\
\hline & $71-80$ & 82 & 2,4299 & ,94058 \\
\hline & $81-90$ & 82 & 2,4268 & ,88409 \\
\hline & $91-100$ & 17 & 2,2059 & 1,02787 \\
\hline & Total & 224 & 2,3750 & ,92366 \\
\hline \multirow{6}{*}{ Yazma stratejileri kullanma } & $51-60$ & 6 & 1,7778 & ,45542 \\
\hline & $61-70$ & 37 & 2,7748 & 99398 \\
\hline & $71-80$ & 82 & 2,6789 & 76881 \\
\hline & $81-90$ & 82 & 2,9350 & ,83549 \\
\hline & $91-100$ & 17 & 2,5490 & 1,06027 \\
\hline & Total & 224 & 2,7545 & ,86953 \\
\hline \multirow{6}{*}{ Toplam } & $51-60$ & 6 & 2,4600 & ,28369 \\
\hline & $61-70$ & 37 & 3,1914 & ,53832 \\
\hline & $71-80$ & 82 & 3,1922 & ,50921 \\
\hline & $81-90$ & 82 & 3,3000 & ,56345 \\
\hline & $91-100$ & 17 & 3,1788 & ,47563 \\
\hline & Total & 224 & 3,2109 & 54100 \\
\hline
\end{tabular}


Tablo 7.1 ve 7.2'de Türkçe öğretmeni adaylarının yazma alışkanlıklarının akademik başarı değişkenlerine göre anlamlı bir farklılık gösterip göstermediği tek yönlü varyans analizi (ANOVA) ile incelenmiştir.

Analiz sonucunda öğretmen adaylarının yazma alışkanlıklarının akademik başarı değişkenlerine göre ölçeğin "yazma stratejileri kullanma" boyutunda anlamlı farklılık gösterdiği belirlenmiştir. $[\mathrm{F}(4,219)=3,304, \mathrm{p}<.05]$. Farkın hangi gruplar arasında olduğunu bulmak amacıyla yapılan Tukey HSD çoklu karşılaştırma testi sonucuna göre; akademik başarı notu 81-90 olan öğrencilerin "yazma stratejileri kullanma alışkanlığına" sahip olanların ortalama puanlarının (X $=2,9350)$, akademik notu 51-60 olan öğrencilere $(X=1,7778)$ göre daha yüksek olduğu söylenebilir. Ölçeğin diğer alt boyutlarında ise anlamlı bir fark oluşmamıştır.

Analiz sonucunda öğretmen adaylarının yazma alışkanlıklarının akademik başarı değişkenlerine göre ölçeğin toplam boyutunda da anlamlı fark gösterdiği belirlenmiştir $[F(4,219)=$ $3,664, p<.05]$. Farkın hangi gruplar arasında olduğunu bulmak amacıyla yapılan Tukey HSD çoklu karşılaştırma testi sonucuna göre; akademik başarı notu 51-60 olan öğrencilerin "yazma alışkanlığının ölçeğin bütün boyutların toplamından elde edilen ortalama puanlarının ( $X=2,4600)$, akademik notu 61-70, ( $X=3,1914)$ 71-80, ( $X=3,1922)$ 81-90, ( $X=3,3000$ ) 91-100 olan öğrencilere $(X=3,1788)$ göre daha düşük olduğu söylenebilir.

Bu verilerden hareketle akademik başarı notu 51-60 olan öğrencilerin yazma alışkanlığına sahip olma durumlarının akademik başarı notu daha yüksek olan öğrencilerin tümüne göre daha düşük seviyede olduğu sonucuna ulaşılmıştır.

\section{Sekizinci Alt Probleme Ait Bulgular}

Araştırmada, "Türkçe öğretmeni adaylarının yazma alışkanlık durumlarının yazılı anlatım dersi başarı değişkenine göre anlamlı düzeyde farklılık göstermekte midir?" olarak ifade edilen sekizinci alt problemle ilgili elde edilen bulgular ve yorumları aşağıda verilmiştir.

Tablo 8.1. Türkçe Öğretmeni Adaylarının Yazma Alışkanlık Durumlarının Yazılı Anlatım Dersi Başarı Değişkenine Göre ANOVA Sonuçları

\begin{tabular}{|c|c|c|c|c|c|c|}
\hline \multicolumn{7}{|c|}{ ANOVA } \\
\hline Boyut & & $\mathrm{KT}$ & $d f$ & KO & $\mathrm{P}$ & Fark (tukey) \\
\hline \multirow{3}{*}{$\begin{array}{l}\text { Yazım kuralları ve } \\
\text { noktalama işaret. uyma }\end{array}$} & Gruplararası & 3,953 & 4 & 988 & $1,741,142$ & \\
\hline & Gruplariçi & 124,325 & 219 & ,568 & & \\
\hline & Toplam & 128,277 & 223 & & & \\
\hline \multirow[t]{2}{*}{ Yazma yeterliliği } & Gruplararası & 6,024 & 4 & 1,506 & 2,053,088 & \\
\hline & Gruplariçi & 160,664 & 219 & ,734 & & \\
\hline
\end{tabular}




\begin{tabular}{|c|c|c|c|c|c|c|}
\hline \multirow{4}{*}{$\begin{array}{l}\text { Yazıyı Edebi tür olarak } \\
\text { kullanma }\end{array}$} & Toplam & 166,688 & 223 & & \multirow[b]{2}{*}{ 2,088, 083 } & \\
\hline & Gruplararası & 4,334 & 4 & 1,083 & & \\
\hline & Gruplariçi & 113,625 & 219 & ,519 & & \\
\hline & Toplam & 117,958 & 223 & & & \\
\hline \multirow{3}{*}{$\begin{array}{l}\text { Yazıyı iletişim aracı } \\
\text { olarak kullanma }\end{array}$} & Gruplararası & 10,218 & 4 & 2,554 & 3,107, 016 & $3<5$ \\
\hline & Gruplariçi & 180,032 & 219 & ,822 & & \\
\hline & Toplam & 190,250 & 223 & & & \\
\hline \multirow{3}{*}{$\begin{array}{l}\text { Yazma stratejileri } \\
\text { kullanma }\end{array}$} & Gruplararası & 15,205 & 4 & 3,801 & 5,427 , 000 & $3<2,4,5$ \\
\hline & Gruplariçi & 153,401 & 219 & ,700 & & \\
\hline & Toplam & 168,607 & 223 & & & \\
\hline \multirow{3}{*}{ Toplam } & Gruplararası & 4,902 & 4 & 1,226 & 4,446, 002 & $5>2,3$ \\
\hline & Gruplariçi & 60,365 & 219 & 276 & & \\
\hline & Toplam & 65,268 & 223 & & & \\
\hline
\end{tabular}

Tablo 8.2. Türkçe Öğretmeni Adaylarının Yazma Alışkanlık Durumlarının Yazılı Anlatım Dersi Başarı Değişkenine ANOVA Sonuçlarının Betimsel Değerleri

\begin{tabular}{|c|c|c|c|c|}
\hline & & $N$ & $x$ & SS \\
\hline \multirow{5}{*}{$\begin{array}{l}\text { Yazım kuralları } \\
\text { ve noktalama } \\
\text { işaret. Uy. }\end{array}$} & $51-60$ & 7 & 3,9524 & 61399 \\
\hline & $61-70$ & 31 & 4,0108 & 96219 \\
\hline & $71-80$ & 82 & 4,1524 & ,78445 \\
\hline & $81-90$ & 77 & 4,2165 & 69725 \\
\hline & $91-100$ & 27 & 4,4877 & ,53694 \\
\hline \multirow{7}{*}{$\begin{array}{l}\text { Yazma } \\
\text { yeterliliği }\end{array}$} & Total & 224 & 4,1890 & ,75844 \\
\hline & $51-60$ & 7 & 3,6735 & 96438 \\
\hline & $61-70$ & 31 & 3,5622 & 66387 \\
\hline & $71-80$ & 82 & 3,6603 & 1,13126 \\
\hline & $81-90$ & 77 & 3,7161 & 64327 \\
\hline & $91-100$ & 27 & 4,1481 & ,50969 \\
\hline & Total & 224 & 3,7251 & 86457 \\
\hline \multirow{3}{*}{$\begin{array}{l}\text { Yazıyı Edebi tür } \\
\text { olarak }\end{array}$} & $51-60$ & 7 & 2,3714 & 1,40204 \\
\hline & $61-70$ & 31 & 2,1806 & ,60300 \\
\hline & $71-80$ & 82 & 2,1098 & ,71052 \\
\hline \multirow[t]{4}{*}{ kullanma } & $81-90$ & 77 & 2,3610 & 66097 \\
\hline & $91-100$ & 27 & 2,4889 & 80447 \\
\hline & Total & 224 & 2,2598 & ,72730 \\
\hline & $51-60$ & 7 & 2,0000 & ,54006 \\
\hline Yazıyı iletişim & $61-70$ & 31 & 2,3871 & 94172 \\
\hline aracı olarak & $71-80$ & 82 & 2,2012 & 89360 \\
\hline \multirow[t]{2}{*}{ kullanma } & $81-90$ & 77 & 2,4156 & ,84352 \\
\hline & $91-100$ & 27 & 2,8704 & 1,12526 \\
\hline
\end{tabular}




$\begin{array}{llrrr} & \text { Total } & 224 & 2,3750 & , 92366 \\ & 51-60 & 7 & 3,3333 & 1,18634 \\ \text { Yazma } & 61-70 & 31 & 3,0000 & , 82552 \\ \text { stratejileri } & 71-80 & 82 & 2,4472 & , 81350 \\ \text { kullanma } & 81-90 & 77 & 2,8139 & , 85583 \\ & 91-100 & 27 & 3,0864 & , 76568 \\ & \text { Total } & 224 & 2,7545 & , 6853 \\ & 51-60 & 7 & 3,1714 & , 52427 \\ & 61-70 & 31 & 3,1381 & , 61312 \\ & 71-80 & 82 & 3,0893 & , 42026 \\ \text { Toplam } & 71-90 & 77 & 3,2488 & , 54100 \\ & 91-100 & 27 & 3,5659 & 3,2109 \\ & \text { Total } & 224 & & \end{array}$

Tablo 8.1 ve 8.2'de Türkçe öğretmeni adaylarının yazma alışkanlıklarının Yazılı Anlatım Dersi akademik başarı notu değişkenlerine göre anlamlı bir farklılık gösterip göstermediği tek yönlü varyans analizi (ANOVA) ile incelenmiştir.

Analiz sonucunda öğretmen adaylarının yazma alışkanlıklarının Yazılı Anlatım Dersi akademik başarı notu değişkenlerine göre ölçeğin "Yazıyı iletişim aracı olarak kullanma ile Yazma stratejileri izlemini kullanma" boyutunda anlamlı fark gösterdiği belirlenmiştir $[F(4,219)=3,107, p<.05]$. [F (4, 219) $=5,427, p<.05]$.

Farkın hangi gruplar arasında olduğunu bulmak amacıyla yapılan Tukey HSD çoklu karşılaştırma testi sonucuna göre; Yazılı Anlatım Dersi akademik başarı notu 71-80 olan öğrencilerin "Yazıyı iletişim aracı olarak kullanma alışanlıklarına" sahip olma ortalama puanlarının $(X=2,2012)$ akademik notu 91-100, (X =2,8704) olan öğrencilere göre daha düşük olduğu söylenebilir.

Yine Yazılı Anlatım Dersi akademik başarı notu 71-80 olan öğrencilerin "Yazma stratejileri izlemini kullanma alışkanlıklarına" sahip olanların ortalama puanlarının $(X=2,4472)$, akademik notu 61-70, (X $=3,0000)$ 81-90 ( $(X=2,8139)$ ve 91-100 olan öğrencilere $(X=3,0864)$ göre daha düşük olduğu söylenebilir. Ölçeğin diğer alt boyutlarında ise anlamlı bir fark oluşmamıştır.

Analiz sonucunda öğretmen adaylarının yazma alışkanlıklarının Yazılı Anlatım Dersi Akademik başarı notu değişkenlerine göre ölçeğin toplam boyutunda ise anlamlı fark gösterdiği belirlenmiştir. [F $(4,219)=4,446, p<.05]$. Farkın hangi gruplar arasında olduğunu bulmak amacıyla yapılan Tukey HSD çoklu karşılaştırma testi sonucuna göre; Yazılı Anlatım Dersi Akademik başarı notu 91-100 olan öğrencilerin "yazma alışkanlığııın ölçeğin bütün boyutların toplamından elde edilen ortalama 
puanlarının ( $X=3,5659)$, Yazılı Anlatım Dersi Akademik akademik notu 61-70, $(X=3,1381)$ 71-80, $(X$ =3,0893) olan öğrencilere göre daha yüksek seviyede olduğu söylenebilir.

Bu verilerden hareketle Yazılı Anlatım Dersi akademik başarı notu 91-100 olan öğrencilerin yazma alışkanlığına sahip olma durumlarının Yazılı Anlatım Dersi akademik başarı notu daha düşük olan öğrencilerin tümüne göre yüksek seviyede olduğu sonucuna ulaşılmıştır.

\section{Dokuzuncu Alt Probleme Ait Bulgular}

Araştırmada, "Türkçe öğretmeni adaylarının yazma alışkanlıklarının sınıf değişkenine göre anlamlı düzeyde farklılık göstermekte midir?" olarak ifade edilen dokuzuncu alt problemle ilgili elde edilen bulgular ve yorumları aşağıda verilmiştir.

Tablo 9.1. Türkçe Öğretmeni Adaylarının Yazma Alışkanlık Durumlarııın sınıf Değişkenine Göre ANOVA Sonuçları

\begin{tabular}{|c|c|c|c|c|c|c|c|}
\hline \multicolumn{8}{|c|}{ ANOVA } \\
\hline Boyut & & KT & Df & KO & $\mathrm{F}$ & $P$ & Fark (tukey) \\
\hline \multirow{3}{*}{$\begin{array}{l}\text { Yazım kuralları ve } \\
\text { noktalama işaret. } \\
\text { uyma }\end{array}$} & Gruplararası & ,554 & 3 & 185 & ,318 & 812 & \\
\hline & Gruplariçi & 127,723 & 220 & ,581 & & & \\
\hline & Toplam & 128,277 & 223 & & & & \\
\hline \multirow{3}{*}{ Yazma yeterliliği } & Gruplararası & 3,420 & 3 & 1,140 & 1,536 & 206 & \\
\hline & Gruplariçi & 163,268 & 220 & ,742 & & & \\
\hline & Toplam & 166,688 & 223 & & & & \\
\hline \multirow{3}{*}{$\begin{array}{l}\text { Yazıyı Edebi tür } \\
\text { olarak kullanma }\end{array}$} & Gruplararası & 4,115 & 3 & 1,372 & 2,650 & ,050 & $4>3$ \\
\hline & Gruplariçi & 113,844 & 220 & ,517 & & & \\
\hline & Toplam & 117,958 & 223 & & & & \\
\hline \multirow{3}{*}{$\begin{array}{l}\text { Yazıyı iletişim aracı } \\
\text { olarak kullanma }\end{array}$} & Gruplararası & 1,358 & 3 & 453 &, 527 & 664 & \\
\hline & Gruplariçi & 188,892 & 220 & 859 & & & \\
\hline & Toplam & 190,250 & 223 & & & & \\
\hline \multirow{3}{*}{$\begin{array}{l}\text { Yazma stratejileri } \\
\text { kullanma }\end{array}$} & Gruplararası & 893 & 3 & 298 & ,390 & ,760 & \\
\hline & Gruplariçi & 167,714 & 220 & ,762 & & & \\
\hline & Toplam & 168,607 & 223 & & & & \\
\hline \multirow{3}{*}{ Toplam } & Gruplararası & ,795 & 3 & ,265 & 905 & ,440 & \\
\hline & Gruplariçi & 64,473 & 220 & 293 & & & \\
\hline & Toplam & 65,268 & 223 & & & & \\
\hline
\end{tabular}


Türkçe Öğretmeni Adaylarının Yazma Alışkanlıkları Üzerine Bir Çalışma

Tablo 9.2. Türkçe Öğretmeni Adaylarının Yazma Alışkanlık Durumlarının Sınıf Değişkenine Göre ANOVA Sonuçlarının Betimsel Değerleri

\begin{tabular}{|c|c|c|c|c|}
\hline & & $\mathrm{N}$ & $x$ & SS \\
\hline \multirow{4}{*}{$\begin{array}{l}\text { Yazım kuralları ve } \\
\text { noktalama } \\
\text { işaret. uyma }\end{array}$} & 1 & 60 & 4,1667 & ,82795 \\
\hline & 2 & 69 & 4,2560 & 71262 \\
\hline & 3 & 44 & 4,1894 & ,69382 \\
\hline & 4 & 51 & 4,1242 & 80059 \\
\hline \multirow{6}{*}{ Yazma yeterliliği } & Total & 224 & 4,1890 & 75844 \\
\hline & 1 & 60 & 3,8167 & 1,26171 \\
\hline & 2 & 69 & 3,7164 & 65899 \\
\hline & 3 & 44 & 3,4935 & 65968 \\
\hline & 4 & 51 & 3,8291 & 64966 \\
\hline & Total & 224 & 3,7251 & 86457 \\
\hline \multirow{4}{*}{$\begin{array}{l}\text { Yazıyı Edebi tür } \\
\text { olarak kullanma }\end{array}$} & 1 & 60 & 2,2133 & 70144 \\
\hline & 2 & 69 & 2,3217 & 69216 \\
\hline & 3 & 44 & 2,0318 & 64114 \\
\hline & 4 & 51 & 2,4275 & ,83140 \\
\hline \multirow{5}{*}{$\begin{array}{l}\text { Yazıyı iletişim aracı } \\
\text { olarak kullanma }\end{array}$} & Total & 224 & 2,2598 & 72730 \\
\hline & 1 & 60 & 2,3417 & 93990 \\
\hline & 2 & 69 & 2,2935 & 98047 \\
\hline & 3 & 44 & 2,4034 & 93264 \\
\hline & 4 & 51 & 2,5000 & ,82462 \\
\hline \multirow{6}{*}{$\begin{array}{l}\text { Yazma stratejileri } \\
\text { kullanma }\end{array}$} & Total & 224 & 2,3750 & 92366 \\
\hline & 1 & 60 & 2,7333 & 93438 \\
\hline & 2 & 69 & 2,6860 & 81826 \\
\hline & 3 & 44 & 2,7727 & 71807 \\
\hline & 4 & 51 & 2,8562 & 98490 \\
\hline & Total & 224 & 2,7545 & 86953 \\
\hline \multirow{5}{*}{ Toplam } & 1 & 60 & 3,2140 & 64804 \\
\hline & 2 & 69 & 3,2157 & 46865 \\
\hline & 3 & 44 & 3,1073 & ,50270 \\
\hline & 4 & 51 & 3,2902 & ,52714 \\
\hline & Total & 224 & 3,2109 & ,54100 \\
\hline
\end{tabular}

Tablo 9.1 ve 9.2'de Türkçe öğretmeni adaylarının yazma alışkanlıklarının sınıf değişkenlerine göre anlamlı bir farklılık gösterip göstermediği tek yönlü varyans analizi (ANOVA) ile incelenmiştir. Analiz sonucunda öğretmen adaylarının yazma alışkanlıklarının sınıf değişkenlerine göre ölçeğin bütün boyutlarının toplamından elde edilen puan ortalamalarına göre anlamlı bir farklılık 
göstermediği belirlenmiştir. [F $(3,220)=, 905$, p >.05]. Ölçeğin sadece "yazıyı edebi tür olarak kullanma boyutunda" ise anlamlı fark gösterdiği belirlenmiştir.

Farkın hangi gruplar arasında olduğunu bulmak amacıyla yapılan Tukey HSD çoklu karşılaştırma testi sonucuna göre; 4. sınıf öğrencilerinin yazma alışkanlık durumlarının ( $X=2,4275)$ ile yazma alışkanlığı durumu $(X=2,0318)$ olan $3 . \operatorname{sınıf~öğrencilerine~göre~daha~yüksek~olduğu~}$ belirlenmiştir.

Bu verilerden hareketle 4. sınıf öğrencilerinin yazma alışkanlığına sahip olma durumlarının yazıyı edebi tür olarak kullanma boyutunda 3. sınıf öğrencilerine göre daha yüksek seviyede olduğu sonucuna ulaşılmıştır.

\section{Tartışma, Sonuç ve Öneriler}

Araştırmadan elde edilen bulgulara göre "Türkçe öğretmeni adaylarının, yazma alışkanlık düzeyleri puan ortalamasının $(X=3,21)$ ile orta seviyede olduğu belirlenmiştir. Bu sonuçlar Özdemir ve Erdem (2011) tarafından yapılan benzer çalışmanın sonuçlarıyla paralellik göstermektedir. Bu sonuçlardan hareketle Türkçe öğretmeni adaylarının yazma alışkanlık düzeylerinin beklenen seviye de olmadığı ama çok düşük seviyede de kalmadığı ifade edilebilir.

Türkçe öğretmeni adaylarının yazma alışkanlıklarının cinsiyet değişkeni açııından ölçeğin bütün boyutlarını oluşturan toplamında anlamlı bir farklılık oluşturmadığı görülmüştür. İstatistiki açıdan anlamlı bir farklılık oluşmamasına rağmen kız öğretmen adaylarının yazma alışkanlıklarının $(X=3,2397)$ erkek öğretmen adaylarına göre $(X=3,1536)$, daha yüksek olduğu söylenebilir. Elde edilen sonuçlardan cinsiyet değişkeninin Türkçe öğretmen adaylarının yazma alışkanlıkları üzerinde etkili olmadığı sonucuna ulaşılmıştır.

Araştırmadan elde edilen diğer sonuç da Türkçe öğretmeni adaylarının yazma alışkanlıklarının serbest yazma etkinlikleri yapma değişkeni açısından ölçeğin bütün boyutlarını oluşturan toplamında anlamlı bir farkın oluşmasıdır. Serbest yazma etkinlikleri yapan Türkçe öğretmeni adaylarının yazma alışkanlıklarının yapmayanlara göre daha yüksek seviyede gelişmiş olduğu söylenebilir.

Türkçe öğretmeni adaylarının yazma alışkanlıklarının serbest yazma etkinlikleri yapmayı sevme değişkeni açısından ölçeğin bütün boyutlarını oluşturan toplamında anlamlı farkın oluştuğu belirlenmiştir. Bu sonuçlardan serbest yazma etkinlikleri yapmayı seven öğretmen adaylarının yazma alışkanlıklarının serbest yazma etkinlikleri yapmayı sevmeyen öğretmen adaylarına göre daha gelişmiş olduğu söylenebilir.

Türkçe öğretmeni adaylarının yazma alışkanlıklarının yazma etkinlikleri yaparken kaygı duyma durumu değişkeni açısından ölçeğin bütün boyutlarını oluşturan toplamında anlamlı farklılık 
oluşturduğu görülmüştür. Sonuçlardan yazma etkinlikleri yaparken kaygı duymayan öğretmen adaylarının yazma alışkanlıklarının yazma etkinlikleri yaparken kaygı duyan öğretmen adaylarına göre daha yüksek olduğu söylenebilir. Bu durum yazma etkinlikleri üzerinde öğrencilerin kaygı duyma durumlarının önemini açıkça ortaya koymaktadır.

Türkçe öğretmeni adaylarının yazma alışkanlıklarının yazma alışkanlığını kazandığını düşünme durumu değişkeni açısından ölçeğin bütün boyutlarını oluşturan toplamında anlamlı fark oluşturduğu görülmüştür. Bu sonuçlardan yazma alışkanlığı kazandığını düşünen öğretmen adaylarının yazma alışkanlığı, kazanmadığını düşünen öğretmen adaylarına göre daha yüksek olduğu tespit edilmiştir.

Yapılan analizler sonucunda öğretmen adaylarının yazma alışkanlıklarının akademik başarı değişkenlerine göre ölçeğin "yazma stratejileri kullanma" boyutunda anlamlı farklılık gösterdiği belirlenmiştir. Verilerden hareketle akademik başarı notu 51-60 olan öğrencilerin yazma alışkanlığına sahip olma durumlarının akademik başarı notu daha yüksek olan öğrencilerin tümüne göre daha düşük seviyede olduğu sonucuna ulaşılmıştır. Bu sonuçlardan hareketle düşük akademik başarı ortalamasına sahip olan öğretmen adaylarının yazma alışanlık düzeylerinin daha düşük olduğu ifade edilebilir.

Türkçe öğretmeni adaylarının yazma alışkanlıklarının Yazılı Anlatım Dersi akademik başarı değişkenlerine göre ölçeğin "Yazıyı iletişim aracı olarak kullanma ile Yazma stratejileri izlemini kullanma" boyutunda anlamlı fark gösterdiği belirlenmiştir. Verilerden hareketle Yazılı Anlatım Dersi akademik başarı notu 91-100 olan öğrencilerin yazma alışkanlığına sahip olma durumlarının Yazılı Anlatım Dersi akademik başarı notu daha düşük olan öğrencilerin tümüne göre yüksek seviyede olduğu sonucuna ulaşılmıştır. Bu sonuçlardan hareketle Yazılı Anlatım derslerinden yüksek not alan öğretmen adaylarının yazma alışkanlıklarının da yüksek seviyede olduğu ifade edilebilir.

Türkçe öğretmeni adaylarının yazma alışkanlıklarının sınıf değişkenlerine göre ölçeğin bütün boyutların toplamından elde edilen puan ortalamalarına göre anlamlı bir fark göstermediği belirlenmiştir. Alan yazında Özdemir ve Erdem (2011) tarafından yapılan benzer çalışmada Türkçe öğretmeni adaylarının yazma alışkanlıklarının sınıf değişkenine göre yazım kurallarına ve noktalama işaretlerine uyma alışkanlıklarının öğrenim gördükleri sınıfa göre istatistiksel olarak anlamlı düzeyde farklılaşma gösterdiği sonucuna ulaşılmıştır. Bu yönüyle yapılan araştırma, Özdemir ve Erdem tarafından yapılan araştırmanın sonuçları ile paralellik göstermemektedir.

\section{Sınırlılıklar}

Araştırma verileri Mehmet Akif Ersoy Üniversitesi Eğitim Fakültesi Türkçe Öğretmenliği bölümünde öğrenim gören öğrencilerle sınırlandırımıştır. 


\section{Öneriler}

Türkçe Öğretmeni adaylarının yazma alışkanlık düzeylerinin beklenen seviyeye yükseltilmesi için gerekli çalışmalara öncelik verilmelidir.

Bütün seviyelerde öğrenim gören öğrencilerin yazma becerinin geliştirilmesi için etkinlik ağırlıklı ders planlamaları yapılmalıdır.

Yazılı metin oluşturmak için hedef kitlede oluşan kaygılar belirlenerek öğrenciler bu kaygılardan uzaklaştırılmalıdır.

Öğrencilerin aktif ve pasif kelime servetinin genişletilmesine yönelik kelime çalışmalarına daha fazla süre ayrılmalıdır.

Yazma becerisinin alışkanlık haline gelmesi demek iyi bir kelime hazinesine sahip olmak demektir. Bu yüzden öğrencilere bol bol kitap okutturulmalı ve yeni öğrenilen kelimelerin yazılan metinlerde kullanılması teşvik edilmelidir.

Illk ve ortaokul basamağından itibaren Türkçe öğretmenleri öğrencileri serbest yazma etkinlikleri yapmaya yönlendirmelidir.

Öğretmen yetiştiren birimlerin lisans derslerine yazma alışkanlığının kazandırıımasını sağlamaya yönelik anadilinde ileri yazma dersleri konulmalıdır.

Türkçe öğretmenleri öğrencilere yazma etkinlikleri yaptırırken öğrencinin yazma becerisinin gelişip gelişmediğini izleyebilmesi için öğrencilerin yazdıkları metinleri saklamalı ve öğrencinin yazma becerisinin ne durumda olduğunu takip etmelidir.

Yazılı Anlatım dersleri teorik bilgi ile sınırlı tutulmamalı öğrencilere metin üretimine yönelik uygulama yapma şansı verilmelidir.

\section{Kaynaklar}

Bağcı, H. (2007). Türkçe öğretmeni adaylarının yazılı anlatıma ve yazılı anlatım derslerine yönelik tutumlarının değerlendirilmesi. TÜBAR, 21, 29-61.

Bülbül, R. A. (2000). Yazılı anlatım ve yazı türleri. Ankara: Nobel Yayın Dağııım.

Büyüköztürk, Ş., Çakmak, E. K., Akgün, Ö. E., Karadeniz, Ş. ve Demirel, F. (2011). Bilimsel araştırma yöntemleri. Ankara: Pegem Akademi Yayınları.

Carter, C.; Bishop, J. ve Kravtes, L. (2002). Key to effective learning (3rd Ed.), New Jersey: Printice Hall.

Çamurcu, D. (2011). Yüksek öğrenime yeni başlayan Türkçe Eğitimi bölümü öğrencilerinin yazma becerilerinin incelenmesi. Türkiyat Araştırmaları Dergisi, 503-518.

Erdem, i. ve Özdemir N. H. (2012). Türkçe öğretmeni adayları için "Yazma Alışkanlığı Ölçeği" geliştirme. Türkiye Sosyal Araştırmalar Dergisi, 16(1),171-194.

Güleryüz, H. (2007). Programlanmıs ilk okuma yazma öğretimi. Ankara: Pegem Akademi Yayınları.

İslamoğlu, A. H. (2009). Sosyal bilimlerde araştırma yöntemleri. i̇stanbul: Beta Basım Yayım Dağııım. 
Karasar, N. (2006). Bilimsel araştırma yöntemi. Ankara: Nobel Yayın-Dağıtım.

Kavcar, C. (1998). Türkçe eğitimi ve sorunları. A.Ü. TÖMER Dil Dergisi, (65), 5-17.

Mete, F. (2015). Türkçe öğretmenliği bölümünde yazma eğitimi dersi: Bilme ve uygulama karşılaştırması. Ana Dili Eğitimi Dergisi, 3(2), 81-91.

Özbay, M. (2006). Türkçe özel öğretim yöntemleri. Ankara: Öncü Yayıncılık.

Özbay, M. (2010). Türkçe öğretimi yazıları. Ankara: Öncü Kitap.

Özdemir, H. ve Erdem, í. (2011). Türkçe öğretmeni adaylarının yazma alışkanlıklarının bazı değişkenler açısından incelenmesi. Uşak Üniversitesi Sosyal Bilimler Dergisi, 4(2), 101-125.

Öztürk, E. (2007). Ilköğretim beşinci sınıf öğrencilerinin yaratıcı yazma becerilerinin değerlendirilmesi. Yayımlanmamış Doktora Tezi, Gazi Üniversitesi, Eğitim Bilimleri Enstitüsü.

Öztürk, K. B. (2012). İlköğretim ikinci kademe öğrencilerinin yazma kaygılarının çeşitli değişkenler açısından incelenmesi. Ç.Ü. Sosyal Bilimler Enstitüsü Dergisi, 21(2), 59-72.

Tural, S. K. (1992). Sorulara cevaplarla kültür, edebiyat, dil. Ankara: Ecdad Yayınevi.

Yılmaz, Y. (2008). Yazma öğretimi, Yeni öğretim programına göre kuramdan uygulamaya Türkçe öğretimi (Editör: Cemal Yıldız). Ankara: Pegem Akademi Yayınları.

\section{Extended Abstract \\ Introduction}

Language is a means of expressing emotional thoughts and desires. There are two learning areas which are comprehending and speaking the language. Writing skill is one of the areas of narrative learning which enables individuals to better express and explain themselves to their interlocutors, as in the case of speaking skill. Writing skills are very important for individuals in terms of communication. The writing skill that enables us to communicate comes out in every moment of our life. In addition, the writing skill is used at points where spoken skills are inadequate. For example, when an application is submitted to an official office, a petition is written. The mode of language is written in similar cases. The writing habits of individuals should be improved so that they can write appropriately in accordance with the rules and structure of the language and the message that the other party wants to convey can be understood easily. Otherwise, effective communication cannot be established. The writing skills that are important for mutual communication are taught to primary school children by primary school teachers in the period of primary education. In Turkish classes, the ability of the students to express emotions, thoughts, impressions, designs and experiences in a correct and effective way depends on their skill development and expressive skills. In this context, it is necessary for the Turkish teachers to inform the students about what and how to write and to ensure that the given information is transformed into practice through application studies. In this case, the writing skill expected from a Turkish teacher is developed. It is because, if the Turkish teacher has not developed his own writing skills, it is unlikely for his students to improve their writing skills. For this reason, it is necessary for a teacher of Turkish instructing the students to have acquired the writing skills and the habit of writing skills. In this study, it was aimed to determine the writing habits of Turkish teacher candidates.

\section{Method}

Descriptive research method was used in this research which aims to find out the writing habits of Turkish teacher candidates. Descriptive research aims to describe the current situation as it is in a context.

\section{Result and Discussion}

Drawing on the results of the research, it was determined that "Turkish teacher candidates have a medium level of writing habits, with an average score of $X=3.21$. It was also observed that the writing habits of Turkish teacher candidates did not have a significant difference in the sum of all dimensions of the scale in terms of the gender variable. It can be said that the writing habits of Turkish teacher candidates were higher than those who did not involve in free activities. It was found that the writing habits of teacher candidates who liked to do free writing activities are higher than the teacher candidates who did not like to do. Further, it can be concluded that the writing habits of the teacher candidates who were not worried about writing activities were higher than the teacher candidates who were. The writing habits of the teacher candidates who thought that they acquired the writing habits were higher than the teacher candidates who thought in the opposite way. It was determined that the habits of the teacher candidates with low success average were low. Writing 
habits of teacher candidates who took higher grades in written expression courses were also at a higher level. It was observed that the writing habits of the Turkish teacher candidates did not show any significant difference according to the average of the points obtained from the sum of all the dimensions in terms of the class variables. This finding was not parallel to the data of a similar study by Özdemir and Erdem (2011). Suggestions which can be made at the end of the study are as follows. Students at all levels should be taught about writing skills. To create written texts, the concerns of the target group should be identified, and they should be eliminated. 